\title{
Game Edukasi Sejarah Gerakan Kemuhammadiyahan dengan Metode Picture and Picture Berbasis Android
}

\author{
Indra Griha Tofik Isa ${ }^{1}$, Asriyanik ${ }^{2}$ \\ ${ }^{1,2}$ Program Studi Teknik Informatika Fak. SAINTEK, Universitas Muhammadiyah Sukabumi \\ 1,2 J1. R. Syamsudin, SH No. 50, Kota Sukabumi, Jawa Barat 43113 \\ E-mail: ${ }^{1}$ igtiku@gmail.com, ${ }^{2}$ asriyanik@gmail.com
}

Masuk: 13 Mei 2017; Direvisi: 15 Juni 2017; Diterima: 21 Juni 2017

\begin{abstract}
Android based Muhammadiyah Movement History education game is one of learning media purposed to learn Muhammadiyah history in MuhammadiyahBased elementary schools much easier and more interesting. This research is carried out since we know that, in reality, learning process about Muhammadiyah history subject usually uses a conventional methodthat is very monotonous. To upgrade students' interest in learning the history of Muhammadiyah, education game is created to solve the problem. Because of its interface and interactive characteristics, students would be more motivated to learn the history of Muhammadiyah. The steps of this research started by collecting the data, analyzing system, designing system, implementing system, and testing and finalizing the system. System design makes use of UML model and animation design uses Adobe Flash software, while Testing uses blackbox testing and user questionnaire. The final result of this research is in the form of a tool for learning proces about history of Muhammadiyah. It can also be a good method for young people to learn more about Muhammadiyah.
\end{abstract}

Keywords: Education Game, Puzzle, Mobile Application, Android

\begin{abstract}
Abstrak. Game Edukasi Sejarah Gerakan Kemuhammadiyahan dengan Metode Picture and Picture Berbasis Android. Game Edukasi Sejarah Gerakan Muhammadiyah Berbasis Android merupakan salah satu media pembelajaran yang ditujukan untuk mempermudah memahami tentang sejarah Muhammadiyah pada Sekolah Dasar berbasis Muhammadiyah. Penelitian ini dibuat karena melihat kondisi yang terjadi di lapangan bahwa proses pembelajaran sejarah gerakan Muhammadiyah sebagian besar dilakukan dengan cara konvensional, sehingga terkesan monoton. Untuk meningkatkan minat pembelajaran sejarah Muhammadiyah, maka dari itu dibuat sebuah game edukasi, karena model tampilan dari game yang interaktif dan menarik diharapakan akan lebih meningkatkan motivasi siswa dalam belajar dan memahami tentang sejarah Muhammadiyah. Tahapan penelitian ini, yaitu dimulai dari pengumpulan data, analisis, perancangan, implementasi, pengujian dan finalisasi sistem. Perancangan sistem dengan pemodelan UML dan perancangan animasi menggunakan Adobe Flash, serta pengujian menggunakan metode blackbox testing dan umpan balik pengguna. Hasil akhir dari penelitian ini secara khusus sebagai alat untuk proses pembelajaran sejarah Muhammadiyah, juga diharapkan dapat menjadi cara kaderisasi yang menarik bagi warga Muhammadiyah sejak dini.
\end{abstract}

Kata kunci: Game Edukasi, Puzzle, Aplikasi Mobile, Android

\section{Pendahuluan}

Pendidikan merupakan sebuah landasan awal bagi perkembangan dan kemajuan sebuah generasi bangsa. Pola pendidikan yang baik menjadi pilar untuk menciptakan generasi yang kompeten dan tangguh. Muhammadiyah merupakan salah satu organisasi di Indonesia yang fokus terhadap pendidikan. Salah satu amal usaha Muhammadiyah adalah gerakan dakwah melalui pendidikan. Tujuan pendidikan dalam Muhammadiyah diantaranya adalah terwujudnya 
manusia muslim yang berakhlak mulia, cakap percaya pada diri sendiri, berguna bagi masyarakat dan negara, beramal menuju terwujudnya masyarakat Islam yang sebenar-benarnya. Untuk mengenal Muhammadiyah, maka hal pertama yang harus diketahui adalah tentang sejarah Muhammadiyah. Sejarah Muhammadiyah ini diperkenalkan sejak dini pada sekolahsekolah yang berbasis Muhammadiyah, mulai dari taman kanak-kanak sampai sekolah menengah.

Kemajuan teknologi sangat membantu dalam pengembangan media pembelajaran. Selama ini kita mengenal beberapa metode pembelajaran aktif seperti Jigsaw, Mind Mapping, Picture and Picture, Cooperative Script (Jasmadi, 2010). Menurut Johnson dalam buku Trianto (2009) disebutkan bahwa metode Picture and Picture adalah salah satu model pembelajaran kooperatif yang menggunakan gambar dan dipasangkan atau diurutkan menjadi urutan logis. Melalui gambar, siswa diharapkan dapat dengan mudah membuat karangan, karena dalam metode ini siswa harus bisa mengurutkan gambar dan membuat sebuah kerangka karangan dari gambar yang telah disediakan. Salah satu teknik yang digunakan dalam menerapkan metode picture and picture adalah dengan menggunakan permainan puzzle (Kusumawati, dkk, 2014). Ada berbagai cara yang dilakukan dalam mengemas permainan puzzle untuk menjadi hal yang menarik dan mudah diterima oleh siswa, salah satunya adalah melalui game edukasi puzzle yang berbasis Teknologi Informasi (TI). Game edukasi yang berbasis TI dengan visualisasi dan alur skenario yang menarik dapat lebih mudah diterima khususnya oleh siswa (Irsa, dkk, 2016), sehingga siswa secara tidak langsung belajar dari game edukasi tersebut. Hal inilah yang mendasari peneliti dalam mengambil ide penelitian, bagaimana mengemas pengenalan gerakan kemuhammadiyahan melalui game puzzle berbasis TI. Materi sejarah Muhammadiyah adalah bagian yang sangat penting dalam proses mengenal gerakan Muhammadiyah. Dalam sekolah berbasis Muhammadiyah, tentu saja sejarah Muhammadiyah adalah bagian yang harus diperkenalkan kepada siswa. Pada saat ini, berdasarkan hasil observasi peneliti di sekolah Muhammadiyah di Sukabumi, proses pembelajaran tentang materi sejarah Muhammadiyah masih bersifat konvensional. Dari tiga kelas sekolah dasar yang telah diobservasi, kurang dari $50 \%$ siswa yang mengetahui sejarah pergerakan Muhammadiyah. Salah satu kendala yang menyebabkan rendahnya pengetahuan siswa adalah siswa merasa bosan dan kurang antusias dalam mempelajari sejarah Muhammadiyah. Diharapkan dengan adanya game edukasi berbasis TI tentang sejarah gerakan Muhammadiyah dapat lebih meningkatkan antusias siswa dalam belajar sehingga pengetahuan siswa tentang sejarah Muhammadiyah dapat meningkat.

Salah satu cara membangun game edukasi berbasis TI adalah dengan menggunakan teknologi flash (Bakri, 2011). Game edukasi berbasis flash dapat dijalankan dalam berbagai platform, yaitu Windows, Android maupun iOS. Melihat perkembangan teknologi yang ada sekarang, yaitu tingkat penggunaan perangkat yang berbasis android, maka game edukasi ini akan dibangun dengan sistem yang berbasis Android. Pada tahun 2015, Waiwai Marketing merilis data bahwa pengguna android di Indonesia mencapai $94 \%$ dari jumlah pengguna smartphone. Sehingga berdasarkan latar belakang tersebut itulah, maka tujuan dari penelitian ini adalah siswa sekolah dasar berbasis Muhammadiyah dapat memahami dan mengenal sejak dini mengenai sejarah Kemuhammadiyahan melalui media berupa game edukasi interaktif puzzle berbasis Android.

\section{Tinjauan Pustaka}

Beberapa penelitian sebelumnya menunjukkan bahwa cara belajar sejarah dengan metode konvensional, yaitu dengan metode ceramah ataupun textbook dinilai kurang efektif dalam pemahaman siswa tentang isi materi. Seperti pada penelitian yang ditulis oleh Widiastuti (2012) yang berjudul Membangun Game Edukasi Sejarah Wali Songo. Isi dari penelitian ini, yaitu tentang upaya meningkatkan proses belajar untuk mengenal tentang Wali Songo pada siswa MI kelas lima, yang merupakan bagian dari pelajaran sejarah. Alur dari game edukasi ini, yaitu seorang pemain game diperintahkan untuk mengumpulkan semua foto Wali Songo yang ada di Indonesia dengan harus melewati tiga rintangan utama, berupa zombiezombie yang ada pada game. Game ini menggunakan algoritma A* dalam membuat pohon 
keputusannya.

Penelitian lainnya ditulis oleh Safrudin (2016), yaitu pembuatan game edukasi sejarah peradaban Islam di Spanyol untuk anak SMA kelas XI yang merupakan salah satu materi dari pelajaran sejarah. Alasan pembuatan penelitian ini, yaitu metode pembelajaran yang monoton tentang pelajaran sejarah. Game edukasi ini dibuat dengan menggunakan Game Engine Contract dan alur dari game menggunakan model game RPG (Role Playing Game). Hasil akhir dari game ini, yaitu sebuah aplikasi game yang dapat dijalankan pada komputer dengan sistem operasi Windows dan mobile dengan sistem operasi Android.

Selain itu Umbaran dan Hermawan (2013) melakukan penelitian yang berjudul Game Edukasi Pembelajaran Sejarah Kemerdekaan Indonesia. Isi dari penelitian ini, yaitu pembuatan game edukasi untuk siswa kelas VIII yang ditujukan untuk memudahkan siswa dalam mempelajari sejarah kemerdekaan. Tipe dari game adalah game adventure, yaitu dimana seorang pemain sedang melakukan liburan ke rumah saudara jauhnya dan diharuskan mengumpulkan bendera Indonesia dari setiap tempat. Bendera dapat dikumpulkan setelah menjawab pertanyaan dengan benar. Hasil implementasi dari game berupa aplikasi game yang dapat dijalankan pada komputer berbasis Windows tanpa harus ada koneksi ke internet.

Penelitian yang dilakukan Putra, dkk (2016) yakni Game Edukasi Berbasis Android Sebagai Media Pembelajaran Untuk Anak Usia Dini, tujuan dari penelitian ini dengan harapan anak-anak dapat langsung menggunakan aplikasi permainan tersebut dan memperoleh pengetahuan lebih banyak serta mengubah pola belajar agar tidak jenuh dan bosan. Game edukasi ini merupakan aplikasi pembelajaran untuk anak usia dini dimulai dari usia tiga sampai enam tahun yang berisi tentang materi pelajaran mengenal binatang, mewarnai, corat-coret, menyanyi serta alfabet. Metode penelitian dan pengembangan aplikasi edukasi ini adalah metode waterfall yang terdiri dari lima tahapan, yaitu requirement, design, implementation, verification, dan maintenance. Dengan menerapkan hasil dari game edukasi ini, diharapkan dapat membantu anak-anak dalam belajar dan dapat meningkatkan pola pikir kreatif serta menambah pengetahuan lebih maju.

Penelitian-penelitian tersebut menunjukkan bahwa tujuan mendasar dari perancangan sebuah game edukasi adalah untuk memudahkan siswa memahami dari kesulitan yang dihadapi dalam proses pembelajaran. Berbagai konsep dan tema seperti RPG, adventure maupun puzzle diterapkan guna membuat game edukasi lebih menarik dan interaktif agar diterima oleh penggunanya terutama usia siswa sekolah dasar.

\section{Metodologi Penelitian}

\subsection{Tahapan Penelitian}

Beberapa tahapan dalam penelitian ini diawali oleh proses analisis dengan melihat spesifikasi kebutuhan perangkat lunak dan perangkat keras serta analisis permasalahan yang terjadi berikut fungsi-fungsi yang diperlukan dalam aplikasi. Tahapan berikutnya proses perancangan sistem, pada tahapan ini dilakukan dengan pemodelan UML serta perancangan animasi dimulai dengan penentuan ide, tema, logline, sinopsis, struktur navigasi, story board dan perancangan tampilan (Ariyati \& Misriyati, 2016). Adapun untuk tahapan penerapan dilakukan dengan pembuatan objek dengan menggunakan aplikasi Adobe Illustrator dan Adobe Photoshop, sedangkan untuk pemrograman menggunakan Adobe Flash dengan bahasa pemrograman ActionScript 3.0. Tahapan pengujian dilakukan dengan pendekatan blackbox testing, dimana melibatkan beberapa user (guru dan siswa) untuk mengetahui kesesuaian fungsionalitas dari aplikasi yang dikembangkan tersebut.

\subsection{Metode Pengembangan Aplikasi}

Metode pengembangan aplikasi dilakukan dengan pendekatan metode waterfall, dimana memiliki kesesuaian dengan tahapan pengembangan aplikasi game edukasi ini, dengan terdapat fase-fase di dalamnya yakni analisis kebutuhan, perancangan dan pemodelan, penerapan, pengujian, dan pemeliharaan (Susanto \& Andriana, 2016). 


\subsection{Partisipan}

Beberapa partisipan dilibatkan dalam penelitian ini baik dalam analisis kebutuhan maupun pengujian adalah tiga orang guru dan 40 orang siswa kelas V di SD Muhammadiyah Goalpara Sukabumi.

\subsection{Tools Pengembangan Aplikasi}

Game edukasi yang dirancang menggunakan teknologi flash yang dapat dioperasikan pada perangkat berbasis Android. Hal ini dikarenakan kemudahan dan kenyamanan flash bagi user tingkat pemula. Perangkat lunak yang digunakan dalam pengembangan aplikasi adalah Adobe Flash sebagai aplikasi pembuat animasi dengan bahasa pemrograman ActionScript 3, sedangkan perancangan animasi dengan menggunakan Adobe Illustrator.

\section{Pembahasan}

\subsection{Perancangan Sistem}

Perancangan sistem menggunakan pemodelan Unified Modeling Language (UML), dimana terdapat beberapa diagram yang digunakan yakni Use Case, Flow of Event, Activity Diagram, Class Diagram. Dalam membuat sebuah Use Case Diagram, terlebih dahulu menentukan aktor yang terlibat dalam sistem (Sulistyorini, 2009). Tabel 1 menunjukkan definisi aktor dan Gambar 1 menunjukan peranan aktor dalam sebuah sistem.

Tabel 1. Aktor yang Ada pada Use Case

\begin{tabular}{clc}
\hline Aktor & \multicolumn{1}{c}{ Definisi } \\
\hline User & $\begin{array}{l}\text { Dalam game edukasi } \\
\text { permainan puzzle, quiz, }\end{array}$ & sejarah Kemilih level yang dikehendaki dan melihat cara bermain \\
\hline
\end{tabular}

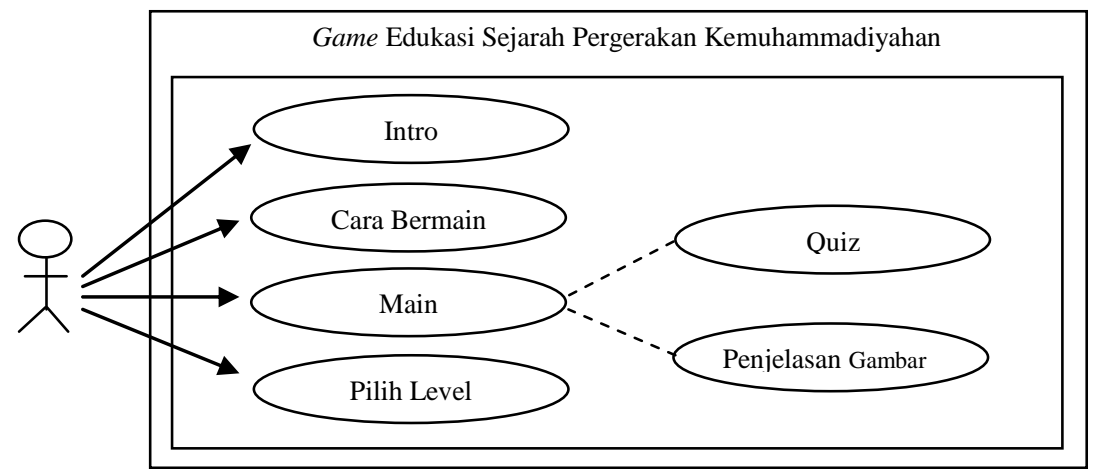

Gambar 1. Use Case Diagram

Flow of event dari use case perancangan game edukasi Sejarah Kemuhammadiyahan berbasis Android terdapat pada Tabel 2 sampai dengan Tabel 5.

Tabel 2. Use Case Intro

\begin{tabular}{|c|c|}
\hline Kebutuhan terkait & $\begin{array}{l}\text { Aktor membutuhkan game edukasi Kemuhammadiyan untuk mengenal sejarah gerakan } \\
\text { Kemuhammadiyahan }\end{array}$ \\
\hline Tujuan & Aktor dapat masuk ke dalam menu utama \\
\hline Kondisi Akhir & Tampil menu utama \\
\hline Aktor Utama & User \\
\hline Pemicu & Aktor telah membuka aplikasi game edukasi sejarah Kemuhammadiyahan \\
\hline \multirow{3}{*}{$\begin{array}{l}\text { Aktor utama / main } \\
\text { flow }\end{array}$} & Langkah \\
\hline & $\begin{array}{ll}\text { Membuka aplikasi game edukasi } & \begin{array}{l}\text { Menampilkan halaman awal dan logo } \\
\text { Muhammadiyah }\end{array} \\
\end{array}$ \\
\hline & Muncul menu utama \\
\hline
\end{tabular}


Tabel 3. Use Case Cara Bermain

\begin{tabular}{|c|c|c|}
\hline Kebutuhan terkait & \multicolumn{2}{|c|}{ Aktor membutuhkan cara bermain untuk mengetahui aturan permainan dari game edukasi } \\
\hline Tujuan & \multicolumn{2}{|l|}{ Aktor dapat masuk ke dalam menu Cara Bermain } \\
\hline Kondisi Akhir & \multicolumn{2}{|l|}{ Tampil menu Cara Bermain } \\
\hline Aktor Utama & \multicolumn{2}{|l|}{ User } \\
\hline Pemicu & \multicolumn{2}{|l|}{ Aktor telah menjalankan menu Cara Bermain } \\
\hline \multirow{3}{*}{$\begin{array}{l}\text { Aktor utama / main } \\
\text { flow }\end{array}$} & Langkah & Sistem \\
\hline & Memilih menu Cara Bermain & Menampilkan halaman Cara Bermain \\
\hline & Menekan tombol "selanjutnya" & $\begin{array}{l}\text { Lanjut ke halaman } 2 \text { Cara Bermain dan kembali ke } \\
\text { Menu Utama }\end{array}$ \\
\hline
\end{tabular}

Tabel 4. Use Case Main

\begin{tabular}{|c|c|c|}
\hline Kebutuhan terkait & \multicolumn{2}{|c|}{ Aktor membutuhkan Main untuk menjalankan game edukasi Kemuhammadiyahan } \\
\hline Tujuan & \multicolumn{2}{|c|}{$\begin{array}{l}\text { Aktor dapat memilih level memainkan game edukasi berupa puzzle tokoh / peristiwa penting / gambar } \\
\text { dan logo dalam gerakan Kemuhammadiyahan }\end{array}$} \\
\hline Kondisi Akhir & \multicolumn{2}{|c|}{ Tampil gambar puzzle acak gerakan Kemuhammadiyahan } \\
\hline Aktor Utama & \multicolumn{2}{|l|}{ User } \\
\hline Pemicu & \multicolumn{2}{|l|}{ Aktor memilih level yang diinginkan } \\
\hline \multirow{3}{*}{$\begin{array}{l}\text { Aktor utama / main } \\
\text { flow }\end{array}$} & Langkah & Sistem \\
\hline & $\begin{array}{l}\text { Menyusun puzzle acak ke dalam } \\
\text { posisi yang tepat }\end{array}$ & $\begin{array}{l}\text { Puzzle akan diam dan divalidasi pada posisi yang } \\
\text { benar dan menambah skor penilaian }\end{array}$ \\
\hline & $\begin{array}{l}\text { Menyusun puzzle acak ke } \\
\text { dalam posisi yang tidak tepat }\end{array}$ & $\begin{array}{l}\text { Puzzle masih dapat digerakan sebelum ditempatkan } \\
\text { pada posisi yang tepat }\end{array}$ \\
\hline
\end{tabular}

Tabel 5 Use Case Pilih Level

\begin{tabular}{|c|c|c|}
\hline Kebutuhan terkait & \multicolumn{2}{|c|}{ Aktor membutuhkan Pilih Level untuk dapat melihat beberapa level pada game edukasi } \\
\hline Tujuan & \multicolumn{2}{|c|}{ Aktor memilih di antara 25 level yang akan dimainkan } \\
\hline Kondisi Akhir & \multicolumn{2}{|l|}{ Membuka permainan puzzle } \\
\hline Aktor Utama & \multicolumn{2}{|l|}{ User } \\
\hline Pemicu & \multicolumn{2}{|l|}{ Aktor memilih level yang diinginkan } \\
\hline \multirow{5}{*}{$\begin{array}{l}\text { Aktor utama / main } \\
\text { flow }\end{array}$} & Langkah & Sistem \\
\hline & Memilih menu Pilih Level & Memunculkan level 1-10 \\
\hline & Menekan tombol "Selanjutnya" & Memunculkan level 11-20 \\
\hline & Menekan tombol "Selanjutnya" & Memunculkan level 21-25 \\
\hline & Memilih level yang diinginkan & Masuk ke dalam game edukasi puzzle \\
\hline
\end{tabular}

\subsection{Perancangan Animasi}

Perancangan animasi dimulai dari penentuan ide (Firdaus, dkk, 2012) yakni sebagai bahan bermain sambil belajar dalam memperkenalkan bagaimana sejarah gerakan Muhammadiyah melalui game puzzle interaktif yang mudah dipahami dan dimengerti oleh siswa. Sehingga tema yang dimunculkan adalah "permainan puzzle sejarah gerakan Kemuhammadiyahan pada zaman kemerdekaan, zaman pergerakan nasional, dan zaman modern". Sinopsis dalam game edukasi ini adalah user harus dapat menyusun puzzle acak sejarah gerakan Kemuhammadiyahan berupa tokoh, simbol organisasi Muhammadiyah, peristiwa penting pada tiga zaman, yakni zaman pergerakan kemerdekaan, zaman pergerakan nasional dan zaman modern. Setelah user menyusun puzzle menjadi gambar utuh, akan muncul scene mengenai keterangan gambar puzzle tersebut. Selanjutnya dalam setiap tiga dan empat puzzle yang sudah dilalui, akan muncul quiz yang mengevaluasi materi yang disampaikan dalam puzzle tersebut. Skenario yang dibuat terdiri dari enam halaman utama, yakni Halaman Intro, Halaman Menu Utama, Halaman Cara Bermain, Halaman Main, Halaman Pilih Level, Halaman Keterangan Gambar dan Halaman Permainan. Dari masing-masing halaman tersebut memiliki scene dan button yang berbeda.

Halaman intro dibuat ke dalam dua scene, scene pertama muncul sebagai menu sambutan yang menampilkan logo Universitas Muhammadiyah Sukabumi dan scene kedua muncul menu transisi menuju menu utama yang memunculkan menu Muhammadiyah. Halaman Menu Utama dibuat kedalam menu tunggal dengan background berupa awan putih dengan langit biru dan terdapat tiga button pilihan yakni button Cara Bermain, button Main dan button Pilih Level. Halaman Cara Bermain dibuat ke dalam dua scene, scene pertama berisi petunjuk 
serta terdapat button selanjutnya dan pilih level sedangkan pada scene kedua berisi petunjuk lanjutan serta terdapat button selanjutnya, sebelumnya dan pilih level. Halaman Main dibuat ke dalam beberapa scene yakni scene pertama berisi gambar puzzle acak dan terbagi ke dalam 25 subscene, scene kedua berisi penjelasan gambar yang akan muncul setelah puzzle tersusun, terbagi kedalam 25 subscene serta scene ketiga berisi quiz yang akan muncul setelah user menyelesaikan tiga puzzle. Halaman Pilih Level dibuat kedalam tiga scene yang berisi pilihan 25 level. Adapun struktur navigasi yang dibuat nampak pada Gambar 2

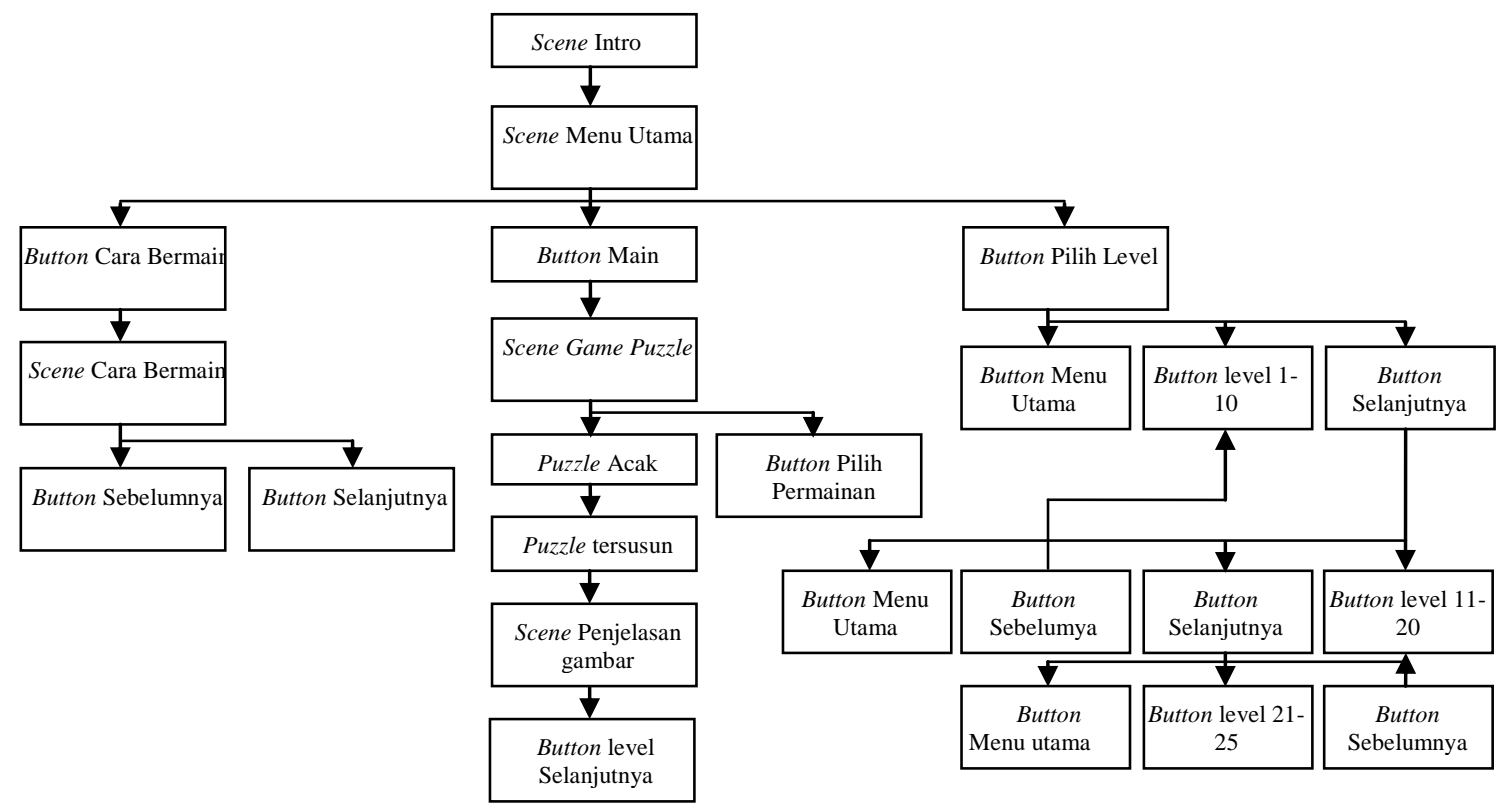

Gambar 2. Struktur Navigasi

Keterangan struktur navigasi: Scene Intro adalah scene yang menunjukan logo UMMI dan Muhammadiyah. Scene Menu Utama adalah scene yang meliputi button pilihan untuk button Cara Bermain, Main, dan Pilih Level. Scene Cara Bermain berisi instruksi permainan yang di dalamnya terdapat button selanjutnya dan sebelumnya. Scene Game puzzle berisi permainan menyusun puzzle acak menjadi gambar utuh, terdapat button pilih permainan. Scene Penjelasan Gambar akan muncul ketika puzzle telah tersusun dan muncul button level selanjutnya. Button pilih level merupakan bagian dari scene pilih level yang di dalamnya terdapat Button Menu Utama, Level 1 - 10, button Selanjutnya.

\subsection{Story Board}

Story board merupakan pengembangan dari story line yang telah dibuat sebelumnya dalam bentuk gambar untuk lebih menjelaskan maksud dari story line tersebut (Indrawaty, dkk, 2013). Story board menunjukan sketsa layout tampilan yang akan dibuat, terdapat beberapa perancangan story board, seperti ditunjukan pada Gambar 3. Keterangan story board: (a) Menu Utama. Menu Utama merupakan tampilan awal setelah aktor membuka aplikasi, dimana aktor dapat memilih beberapa pilihan yakni Cara Bermain, Main dan Pilih Level. Menu utama akan tampil setelah muncul scene intro. (b) Pilih Level. Dalam menu pilih level, aktor dapat memilih level 1-10 untuk scene pertama. Ketika menekan tombol panah kanan (selanjutnya), maka akan muncul scene kedua yang berisi button 11-20. Pada scene kedua terdapat button panah kiri (menunjukan scene sebelumnya), dan button panah kanan (menunjukkan scene selanjutnya). (c) Permainan Puzzle Acak. Aktor dapat menyusun puzzle acak untuk disusun menjadi gambar utuh. Jika puzzle mengenai posisi yang tepat maka otomatis akan terkunci dan akan menambah skor. (d) Penjelasan Gambar. Scene ini akan muncul otomatis setelah aktor menyelesaikan penyusunan gambar puzzle. Aktor akan memperoleh informasi mengenai puzzle yang telah 
disusun menjadi gambar utuh. Untuk melanjutkan ke level berikutnya, aktor dapat menekan button level selanjutnya. (e) Quiz. Quiz akan muncul setelah aktor menyelesaikan permainan sebanyak tiga puzzle. Quiz yang ditampilkan berupa pertanyaan dengan pilihan ganda. Soal yang diberikan berasal dari materi puzzle yang dimainkan oleh aktor. (f) Pernyataan Benar/Salah. Bila aktor menjawab secara tepat, maka akan muncul simbol BENAR pada scene quiz dan akan menambah nilai skor. Sedangkan bila aktor menjawab tidak tepat, maka akan muncul simbol SALAH dan tidak menambah nilai skor.

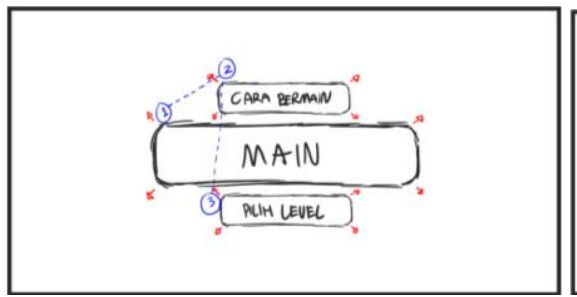

(a)

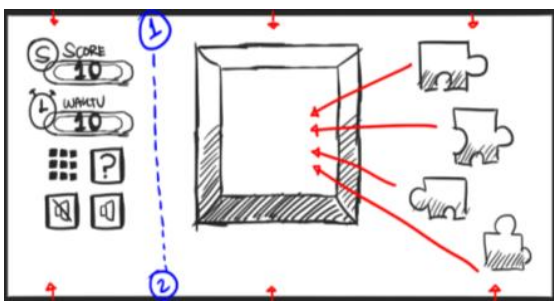

(c)

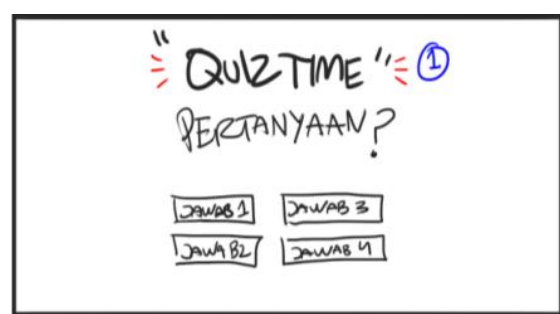

Gambar 3. Storyboad : (a) Menu Utama, (b) Pilih Level, (c) Permainan Puzzle Acak, (d) Penjelasan

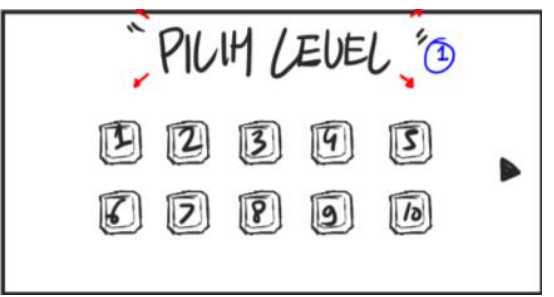

(b)

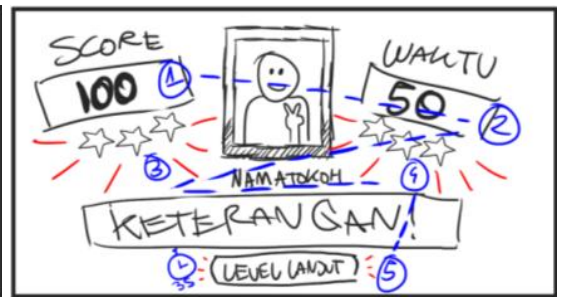

(d) Gambar, (e) Quiz, (f) Pernyataan Benar / Salah

\subsection{Implementasi Program}

Perancangan gambar menggunakan Adobe Photoshop dan Adobe Illustrator, sedangkan untuk animasi menggunakan Adobe Flash dengan bahasa pemrograman Action Script 3. Berikut ini adalah tampilan dari implementasi program game edukasi puzzle pada Gambar 4.
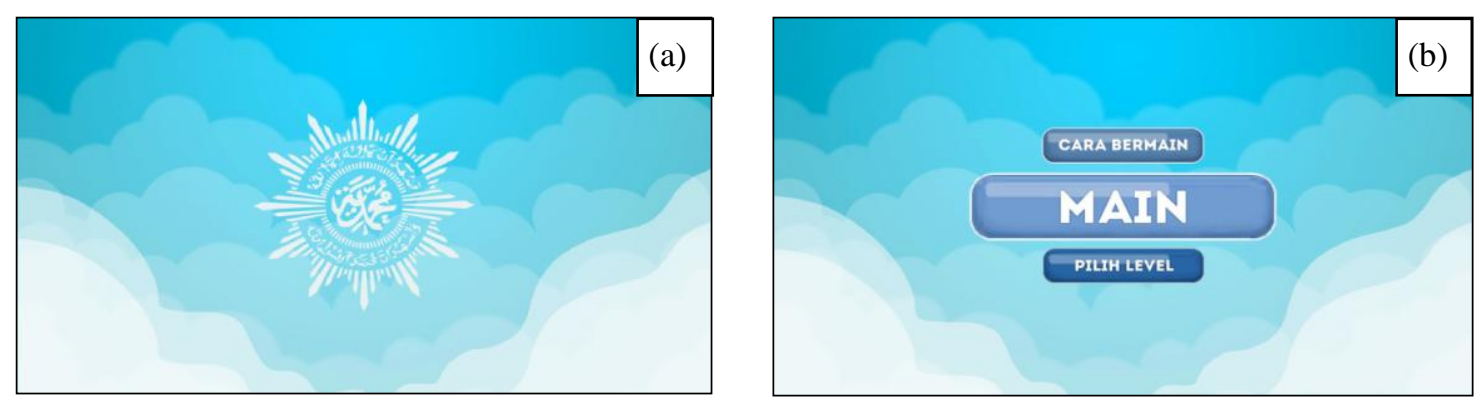

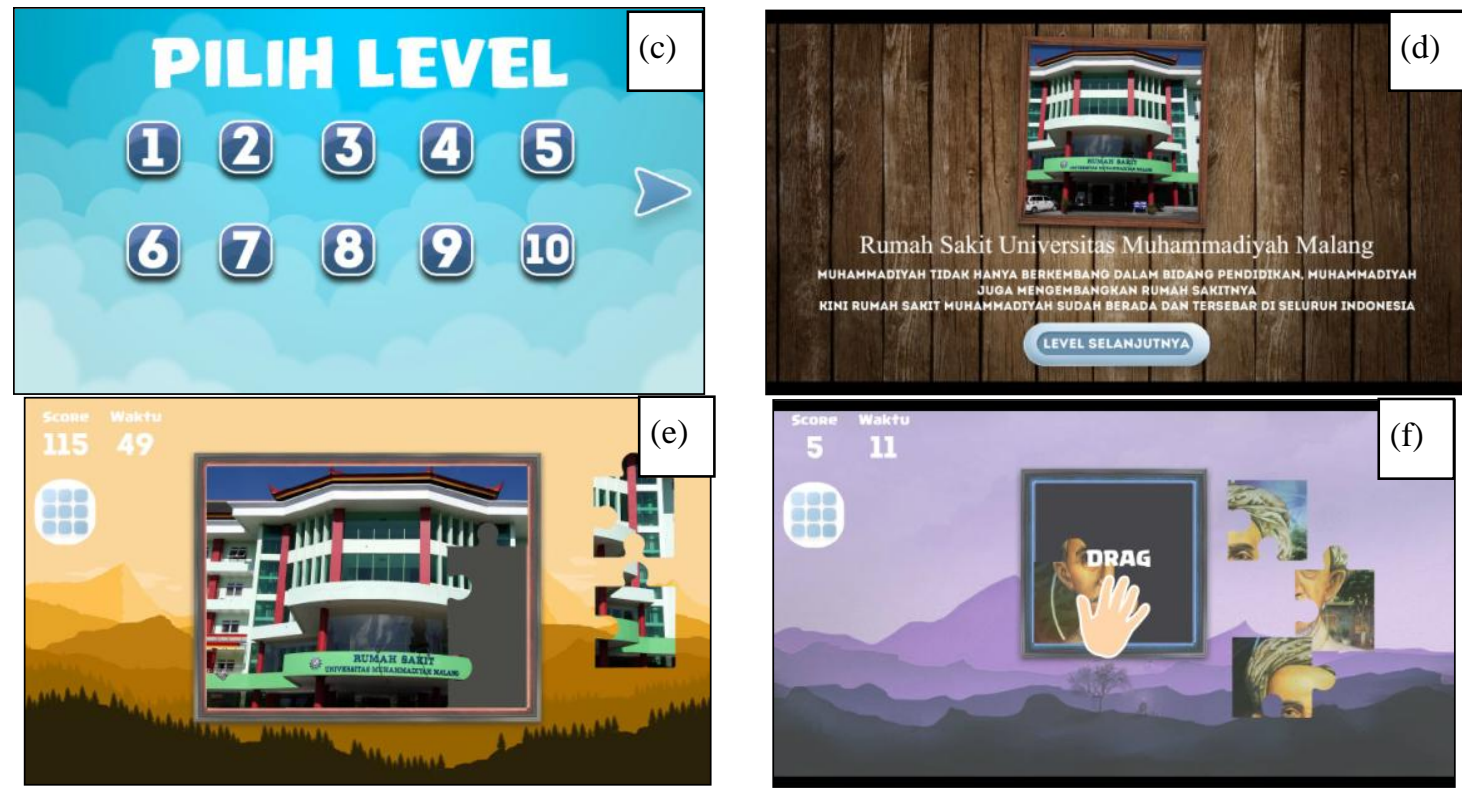

Gambar 4. (a) Tampilan Animasi Intro, (b) Tampilan Animasi Menu Utama(c) Tampilan Animasi Pilih Level, (d) Tampilan Animasi Penjelasan Gambar, (e) Tampilan Animasi Game puzzle, (f) Tampilan Animasi Petunjuk Permainan

\subsection{Pengujian Program}

Pengujian program dilakukan dengan dua metode, yakni dengan blackbox testing guna mengetahui kesesuaian aspek fungsionalitas sistem yang dijalankan, serta penyebaran pertanyaan untuk mengetahui pemahaman siswa mengenai materi sejarah gerakan Kemuhammadiyahan setelah menggunakan game edukasi ini. Teknis pengujian dilakukan dengan pemberian skenario pengujian kepada responden guru dan siswa secara bergantian. Durasi pengujian dilakukan selama beberapa tiga sesi, dengan masing-masing sesi selama 40 menit. Berikut ini adalah hasil dari blackbox testing pada Tabel 6.

Tabel 6. Hasil Blackbox Testing

\begin{tabular}{|c|c|c|c|c|}
\hline No & $\begin{array}{l}\text { Deskripsi } \\
\text { Pengujian }\end{array}$ & Skenario Pengujian & Hasil yang dicapai & Berhasil \\
\hline 1 & Proses Masuk & $\begin{array}{l}\text { Memilih salah satu button yang } \\
\text { terdapat dalam menu utama }\end{array}$ & $\begin{array}{l}\text { Button pada menu utama berfungsi } \\
\text { dengan baik, menavigasikan pada menu- } \\
\text { menu selanjutnya seperti Cara Bermain, } \\
\text { Main dan Pilih Level }\end{array}$ & Berhasil \\
\hline 2 & $\begin{array}{l}\text { Masuk ke Menu } \\
\text { Cara Bermain }\end{array}$ & $\begin{array}{l}\text { Menekan tombol navigasi } \\
\text { selanjutnya dan sebelumnya }\end{array}$ & $\begin{array}{l}\text { Button berfungsi dengan baik, } \\
\text { mengarahkan pada halaman Cara Bermain } \\
\text { berikutnya maupun sebelumnya }\end{array}$ & Berhasil \\
\hline 3 & $\begin{array}{l}\text { Memainkan game } \\
\text { Puzzle }\end{array}$ & $\begin{array}{l}\text { Puzzle diletakan pada posisi yang } \\
\text { tepat }\end{array}$ & $\begin{array}{l}\text { Puzzle akan otomatis mengunci bila pada } \\
\text { posisi yang tepat dan akan menambah } \\
\text { skor }\end{array}$ & Berhasil \\
\hline 4 & $\begin{array}{l}\text { Memainkan game } \\
\text { Puzzle }\end{array}$ & $\begin{array}{l}\text { Puzzle diletakan pada posisi yang } \\
\text { tidak tepat }\end{array}$ & $\begin{array}{l}\text { Puzzle masih dapat dipindahkan dan } \\
\text { digeser sebelum ditempatkan pada posisi } \\
\text { yang tepat }\end{array}$ & Berhasil \\
\hline 5 & Puzzle tersusun & $\begin{array}{l}\text { Puzzle disusun dan diperoleh } \\
\text { suatu gambar }\end{array}$ & $\begin{array}{l}\text { Muncul secara otomatis scene penjelasan } \\
\text { gambar dan button level selanjutnya }\end{array}$ & Berhasil \\
\hline 6 & Menjawab Quiz & Menjawab dengan Jawaban Benar & $\begin{array}{l}\text { Skor bertambah dan muncul simbol } \\
\text { BENAR }\end{array}$ & Berhasil \\
\hline 7 & Menjawab Quiz & Menjawab dengan Jawaban Salah & $\begin{array}{l}\text { Skor tidak bertambah dan muncul simbol } \\
\text { SALAH }\end{array}$ & Berhasil \\
\hline 8 & $\begin{array}{l}\text { Masuk ke Menu } \\
\text { Pilih Level }\end{array}$ & Memilih Level antara 1-25 & $\begin{array}{l}\text { Muncul halaman game puzzle sesuai } \\
\text { dengan level yang dipilih pada menu Pilih } \\
\text { Level }\end{array}$ & Berhasil \\
\hline 9 & $\begin{array}{l}\text { Memunculkan } \\
\text { scene SELAMAT }\end{array}$ & Memainkan game pada level 25 & $\begin{array}{l}\text { Setelah berhasil menyusun puzzle pada } \\
\text { level } 25 \text { maka muncul scene SELAMAT } \\
\text { KAMU BERHASIL }\end{array}$ & Berhasil \\
\hline
\end{tabular}


Pengujian berikutnya dilakukan untuk mengetahui tingkat pemahaman siswa terhadap materi yang diberikan, pada analisis awal telah dilakukan sebaran pertanyaan untuk mengetahui tingkat pemahaman siswa sebelum memainkan game edukasi Sejarah Kemuhammadiyahan. Pengujian melibatkan siswa Sekolah Dasar Muhammadiyah Sukabumi dengan 40 jumlah siswa dari kelas lima dengan pertanyaan-pertanyaan yang sama dengan analisis awal. Tabel 7 menunjukan persentasi pemahaman siswa terhadap pertanyaan-pertanyaan yang diberikan, sebelum dan sesudah memainkan game puzzle Sejarah Kemuhammadiyahan.

Tabel 7. Hasil Perbandingan Pemahaman Siswa

\begin{tabular}{llcc}
\hline \multirow{2}{*}{ No } & Pertanyaan & \multicolumn{2}{c}{ Persentase jawaban benar } \\
\cline { 3 - 4 } & & $\begin{array}{c}\text { Analisis } \\
\text { awal }\end{array}$ & $\begin{array}{c}\text { Setelah memainkan } \\
\text { Game Edukasi }\end{array}$ \\
\hline 1 & Siapakah pendiri Organisasi Muhammadiyah ? & $20 \%$ & $93 \%$ \\
\hline 2 & Kapan Organisasi Muhammadiyah didirikan? & $5 \%$ & $75 \%$ \\
\hline 3 & Apa Kepanjangan dari IPM? & $15 \%$ & $85 \%$ \\
\hline 4 & Sebutkan salah satu ketua Muhammadiyah yang kamu ketahui & $78 \%$ \\
\hline 5 & Muhammadiyah merupakan organisasi Islam yang bergerak di bidang... & $10 \%$ & $70 \%$ \\
\hline 6 & Sebutkan pahlawan yang berlatar belakang dari Muhammadiyah? & $10 \%$ & $75 \%$ \\
\hline 7 & Apa yang kamu ketahui tentang Hibul Wathan? & $15 \%$ & $83 \%$ \\
\hline & Rata-rata & $\mathbf{1 1 \%}$ & $\mathbf{8 0 \%}$ \\
\hline
\end{tabular}

Dari Tabel 7 di atas dapat kita ketahui bagaimana pemahaman siswa terhadap materi sejarah Muhammadiyah dengan melakukan analisis awal lalu membandingkan setelah siswa memainkan game edukasi. Dapat dilihat pada tabel bahwa rata-rata siswa yang menjawab pertanyaan dengan benar adalah $11 \%$, artinya dari 40 siswa yang menjawab pertanyaan, hanya sekitar empat siswa saja yang menjawab dengan benar. Namun setelah memainkan game edukasi, angka rata-rata siswa yang menjawab pertanyaan dengan benar sebanyak $80 \%$. Artinya siswa yang menjawab dengan benar melonjak naik menjadi 32 siswa. Hal ini mengindikasikan bahwa penggunaan media pembelajaran seperti game edukasi dapat menjadi alternatif dalam meningkatkan pemahaman siswa mengenai materi yang diajarkan.

\section{Kesimpulan}

Media pembelajaran dapat dilakukan dengan berbagai metode, salah satunya dengan game edukasi. Pada penelitian yang dilakukan telah dibuktikan bahwa media pembelajaran melalui game edukasi dapat meningkatkan pemahaman siswa dalam memahami materi yang diberikan. Game edukasi dikemas ke dalam puzzle interaktif serta dengan penyisipan quiz berbasis Android. Pengujian aspek fungsional dilakukan dengan blackbox testing dan dinyatakan dengan berhasil, sedangkan pengujian dari hasil kemampuan pemahaman pengguna menunjukkan hasil yang baik, semula tingkat pemahaman siswa hanya $11 \%$, setelah dilakukan permainan game edukasi naik menjadi $80 \%$.

Adapun yang menjadi saran dalam penelitian ini perlunya penambahan suara yang lebih interaktif disesuaikan dengan segmentasi pengguna yakni anak usia Sekolah Dasar serta tingkat kesulitan puzzle dapat ditambahkan dengan potongan-potongan yang lebih banyak misalnya $5 \mathrm{x}$ $4,5 \times 5$ dan $6 \times 6$. Strategi pengujian dapat dikembangkan dengan pendekatan usability testing dan/atau user experience questionnaire, sehingga hasil pengujian dapat lebih objektif guna pengembangan di kemudian hari.

\section{Ucapan Terima Kasih}

Ucapan terima kasih disampaikan kepada DIKTILITBANG Muhammadiyah atas sumbangsih dan dukungannya dalam penelitian ini.

\section{Referensi}

Ariyati, S., \& Misriati, T. (2016). Perancangan Animasi Interaktif Pembelajaran Asmaul Husna. Jurnal Teknik Komputer, 2(1): 116-121. 
Bakri, H. (2011). Desain Media Pembelajaran Animasi Berbasis Adobe Flash CS3 Pada Mata Kuliah Instalasi Listrik 2. Jurnal Medtek, 3(2).

Firdaus, S., Damiri, D. J., \& Tresnawati, D. (2012). Perancangan Aplikasi Multimedia Interaktif Company Profile Generic (Studi Kasus CV. Ganetic). Jurnal Algoritma, 9(01).

Indrawaty, Y., Rosmala, D., \& Ramdhanial, A. M. (2013). Aplikasi Pembelajaran Alat Musik Gitar menggunakan Model Skenario Multimedia Interaktif Timeline Tree. Jurnal Informatika, 4(1), 2.

Irsa, D., Saputra, R. W., \& Primaini, S. (2016). Perancangan Aplikasi Game Edukasi Pembelajaran Anak Usia Dini Menggunakan Linear Congruent Method (LCM) Berbasis Android. Jurnal Informatika Global, 6(1): 7-14.

Jasmadi. (2010). Menyusun Presentasi Pembelajaran Berbasis TIK dengan MS Office 2010. Jakarta: PT. Elex Media Komputindo

Kusumawati, K. D., Jampel, I. N., \& Parmiti, D. P. (2014). Penerapan Picture and Picture dengan Media Puzzle untuk Meningkatkan Perkembangan Kognitif Anak. Jurnal Pendidikan Anak Usia Dini, 2(1): 101-111.

Putra, D. W., Nugroho, A. P., \& Puspitarini, E. W. (2016). Game Edukasi Berbasis Android Sebagai Media Pembelajaran Untuk Anak Usia Dini. JIMP-Jurnal Informatika Merdeka Pasuruan E-ISSN 2503-1945, 1(1): 46-58.

Rahmawati, N. F., Julia, J., \& Iswara, P. D. (2016). Penerapan metode Picture and Picture dan Permainan Jelajah EYD untuk Meningkatkan Keterampilan Menulis Karangan. Pena Ilmiah, 1(1): 891-900.

Safrudin, W.E. (2016). Game Edukasi Sejarah Peradaban Islam di Spanyol Berbasis Multiflatform. Surakarta: UMS.

Sulistyorini, P. (2009). Pemodelan Visual dengan Menggunakan UML dan Rational Rose. Dinamik-Jurnal Teknologi Informasi, 14(1): 23-29.

Susanto, R., \& Andriana, A. D. (2016). Perbandingan Model Waterfall dan Prototyping dalam Pengembangan Sistem Informasi. Majalah Ilmiah UNIKOM, 14(1): 41-46.

Trianto. (2009). Mendesain Model Pembelajaran Inovatif-Progresif. Jakarta: Kencana Prenada Group

Umbaran, D.J. \& Hermawan, G. (2013). Game Edukasi Pembelajaran Sejarah Kemerdekaan Indonesia. Prosiding The $14^{\text {th }}$ Seminar on Inteligent and Its Applications.

Widiastuti, N. I. (2012). Membangun Game Edukasi Sejarah Walisongo. Komputa: Jurnal Ilmiah Komputer dan Informatika, 1(2). 